ctase assay in intact plant es. Commun. 43: 1274

ase from pig heart. - In Colowick and N. O. KapPress, New York.

ieringa, F. 1982. Effect of nitrate accumulation in Z. Pflanzenphysiol. 107:

Daily changes in nitrate nitrate in spinach, grown lant. 66: 550-556. nitrogen and carbon meext. - In Physiological, f Nitrogen Metabolism in Neeteson and I. Stulen, nd W. Junk, Den Haag,

ogen metabolism in spin$-195$.

85. Nitrate accumulation ryegrass (Lolium multi211-218.

PHYSIOL. PLANT. 66: 563-568. Copenhagen 1986

\title{
The effect of isoproturon on root growth and ultrastructure of the photosynthetic apparatus of two wheat cultivars and a weed
}

\author{
M. R. de Felipe, J. M. Pozuelo, M. M. Lucas and F. Fernández del Campo
}

\begin{abstract}
de Felipe, M. R., Pozuelo, J. M., Lucas, M. M. and Fernández del Campo, F. 1986. The effect of isoproturon on root growth and ultrastructure of the photosynthetic apparatus of two wheat cultivars and a weed. - Physiol. Plant. 66: 563-568
\end{abstract}

The effect of isoproturon [N,N-dimethyl N'4-(1-methyl-ethyl) phenyl urea] on the germination, growth of root and ultrastructure of the photosynthetic apparatus was investigated in two wheat cultivars (Triticum sativum L. cvs Castan and Esquilache) and a weed (Lolium rigidum Gaud.). No inhibition of germination was apparent in any of the three plants studied. The inhibition of root growth was considerably significant, especially in cv. Esquilache. After $48 \mathrm{~h}$ treatment with isoproturon $(340 \mu M)$, the chloroplasts of the two wheat cultivars were found to be similar, showing a higher number of grana with fewer thylakoids per granum (lower stacking degree), broader grana stacks than in the control and an absence of starch. However, after $60 \mathrm{~h}$ of treatment, swelling of the thylakoids occurred in the Esquilache cultivar.

The rye grass was the most affected by the herbicide; at low concentration $(3.4 \mu M)$ the number and size of the grana decreased considerably and the stroma thylakoids were destroyed. At higher concentration $(17 \mu M)$, there was a strong accumulation in certain areas of the stroma of a substance with a lipid-like appearance, probably derived from the disintegrating thylakoids. At the same concentrations some chloroplast envelopes were completely desintegrated.

The Hill reaction of the three plants exhibited a similar sensitivity towards the herbicide.

Additional key words - Chloroplasts, herbicide action, root growth, rye grass, wheat.

M. R. de Felipe (reprint requests), J.M. Pozuelo and M. M. Lucas, Instituto de Edafología y Biología Vegetal, Serrano 115 Dpdo., 28006 Madrid, Spain; F. Fernández del Campo, Dep de Botánica y Fisiología Vegetal, Univ. Autónoma, 28049 Madrid, Spain.

\section{Introduction}

Most urea herbicides can greatly alter the photosynthetic machinery, both at a structural and functional level, since they interfere with chloroplast development and with photosynthetic activity. In the case of phenylureas the impairment of the photosynthetic activity is usually due to an inhibition of the electron transport (Moreland 1980, van Rensen 1982). The aim of the present work was to compare some of the effects that isoproturon (a phenylurea derivate) exerts on two wheat cultivars and on a rye grass, especially at the structural level.

We were particularly interested in the effect of isoproturon, since it is used in several parts of Spain to ar- rest the growth of certain rye grasses (González Ponce and Rodríguez Señas 1983). In spite of its relatively wide use, however, no data are available on the structural damage that isoproturon may cause to wheat and weeds. We have compared the effect of isoproturon on germination, root growth and on the photosynthetic system of the two wheat cultivars, Castan and Esquilache, and of the rye grass Lolium rigidum Gaud., one of the most abundant weeds in our wheat fields. Special attention has been paid to the possible induction of a shadetype adaptation response in chloroplasts, as has been shown in the case of monuron (Klein and Newman 1966), fluometuron (Wergin and Potter 1975), methabenthiazuron (Fedtke et al. 1977) and bentazon (Meier and Lichtenthaler 1981). 


\section{Materials and methods}

To study the effect of isoproturon on germination, seeds of Triticum sativum L. cvs Castan and Esquilache and Lolium rigidum Gaud. were left in covered Petri dishes on filter paper with either water or solutions of the herbicide $(1-340 \mu M)$ and allowed to germinate at $28^{\circ} \mathrm{C}$ with a relative humidity of $70 \%$.

For root growth and electron microscopy experiments, unsterilized seeds were placed on plastic meshes to germinate over containers filled with distilled water. Five-day-old seedlings (five day-etiolated) were grown in a slightly modified half-strength Hoagland nutrient solution (Pozuelo and Ulrich 1967) in a climate chamber $\left(25^{\circ} \mathrm{C}, 70 \%\right.$ relative humidity) with continuous light (Philips TLP $65 \mathrm{~W} / 33 \mathrm{I}, 190 \mu \mathrm{mol} \mathrm{m} \mathrm{m}^{-2} \mathrm{~s}^{-1}$ ). The herbicide, at the same concentrations as used for germination, was added to the nutrient solution at the beginning of the illumination period. Root growth was studied by measuring the length of the roots and also the weight after 48 h.

Cotyledon samples were taken after 48 and 60 h illumination. Small segments were fixed in $3 \%(\mathrm{v} / \mathrm{v})$ glutaraldehyde in $0.05 \mathrm{M}$ Na-cacodylate ( $\mathrm{pH} 7.4$ ) for $3 \mathrm{~h}$ at $4^{\circ} \mathrm{C}$, and post-fixed in a buffered $2 \% \mathrm{OsO}_{4}$ for $2 \mathrm{~h}$. After dehydration, embedding was performed in Araldite (Durcupan ACM) following conventional methods. U1trathin leaf sections were cut with a diamond knife (Dupont 32525) fitted to a Reichert ultramicrotome, poststained with lead citrate (Reynolds 1963) and later examined with a Philips 300 at $80 \mathrm{kV}$.

An Image Analyser (Kontron MOP Videoplan) was used for taking the measurements from the electron micrographs of the plants studied.

The "form perimeter" and the "form area" were determined according to: Form perimeter $=4 \pi \cdot$ area/perimeter $^{2}$; form area $=4 \cdot \operatorname{area} /(\pi \cdot a \cdot b)$, where $a$ is the minimum and $\mathrm{b}$ the maximum diameter.

Subchloroplast particles were obtained from chloroplasts through disruption by osmotic shock. Chloroplasts were prepared according to Whatley and Arnon (1963). Chlorophyll was estimated by the method of Arnon (1949).

Tab. 1. Effect of isoproturon on the development of young roots of T. sativum cvs Esquilache and Castan, and L. rigidum Gaud. Each value is the mean \pm SD of 12 plants.

${ }^{*},{ }^{* *}$, differs from the control at the 5 and $1 \%$ level, respectively. RL, root length in $\mathrm{mm}$; RW, root weight in $\mathrm{mg}$.

\begin{tabular}{|c|c|c|c|}
\hline \multirow{2}{*}{ Parameter } & & \multicolumn{2}{|c|}{ Isoproturon concentrations $(\mu M)$} \\
\hline & & 0 & 34 \\
\hline \multirow[t]{2}{*}{ Esquilache } & RL & $433 \pm 190$ & $210 \pm 60^{*}$ \\
\hline & RW & $40 \pm 23$ & $9 \pm 3^{* *}$ \\
\hline \multirow[t]{2}{*}{ Castan } & RL & $544 \pm 212$ & $266 \pm 52 *$ \\
\hline & RW & $94 \pm 47$ & $28 \pm 9^{*}$ \\
\hline \multirow[t]{2}{*}{ L. rigidum } & RL & $145 \pm 54$ & $86 \pm 20^{*}$ \\
\hline & RW & $1.0 \pm \quad 0.9$ & $0.3 \pm 0.2$ \\
\hline
\end{tabular}

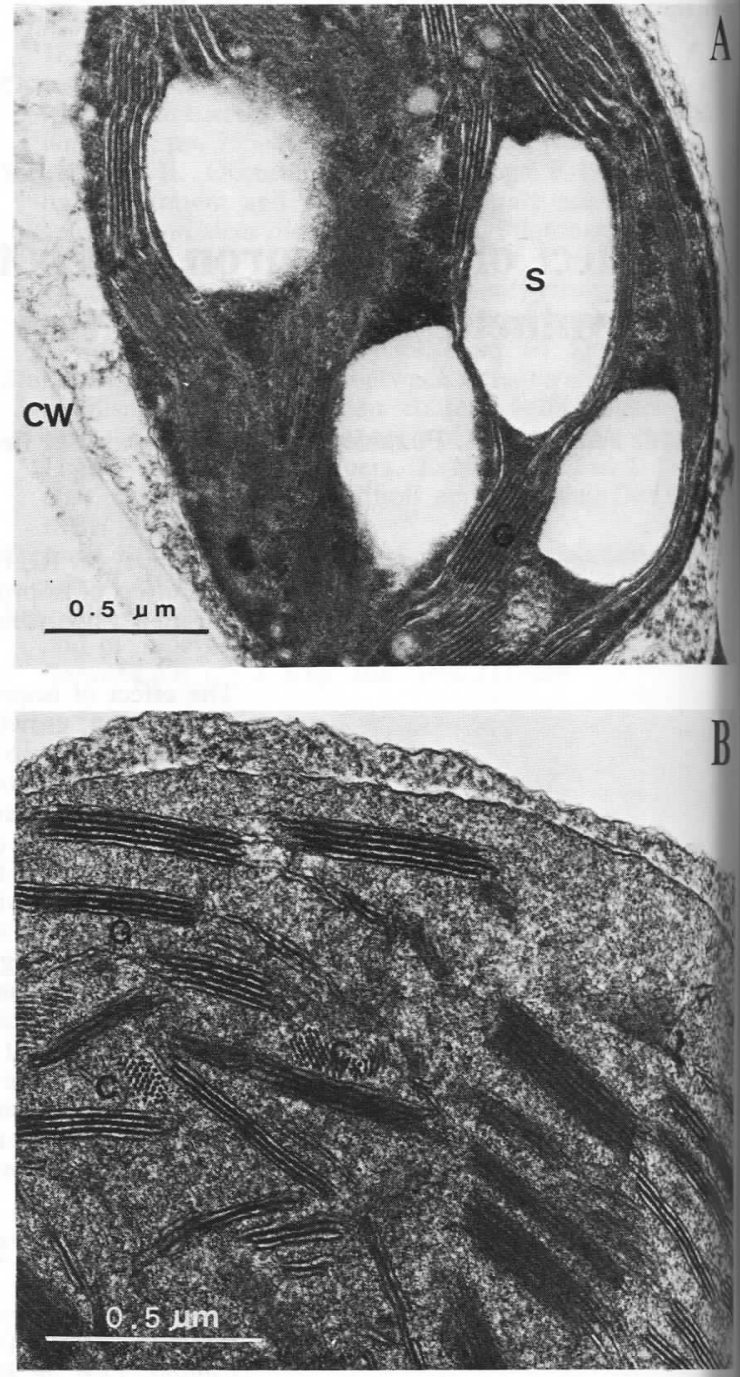

Fig. 1. Electron micrographs of chloroplasts from 5-day-old wheat cotyledon $\mathrm{cv}$. Castan greened for $48 \mathrm{~h}$. A, control plant $\mathrm{B}$, treatment with $340 \mu \mathrm{M}$ isoproturon; $\mathrm{C}$, crystalline inclusions; CW, cell wall; G, granum; S, starch.

Photoreduction of ferricyanide was carried out for min in open test tubes immersed in a water bath thermostated at $25^{\circ} \mathrm{C}$. The fluence rate used was $140 \mu \mathrm{mo}$ $\mathrm{m}^{-2} \mathrm{~s}^{-1}$. The reaction was interrupted by the addition 0 . trichloroacetic acid. After centrifugation of the reaction mixtures, the ferricyanide present was determined spectrophotometrically by the absorbance at $420 \mathrm{~nm}$.

\section{Results and discussion}

Isoproturon in the 34-340 $\mu M$ range hardly affected germination, either in wheat plants or weed, but significantly diminished root growth in the three plants used, especially in the wheat cv. Esquilache (Tab. 1). 

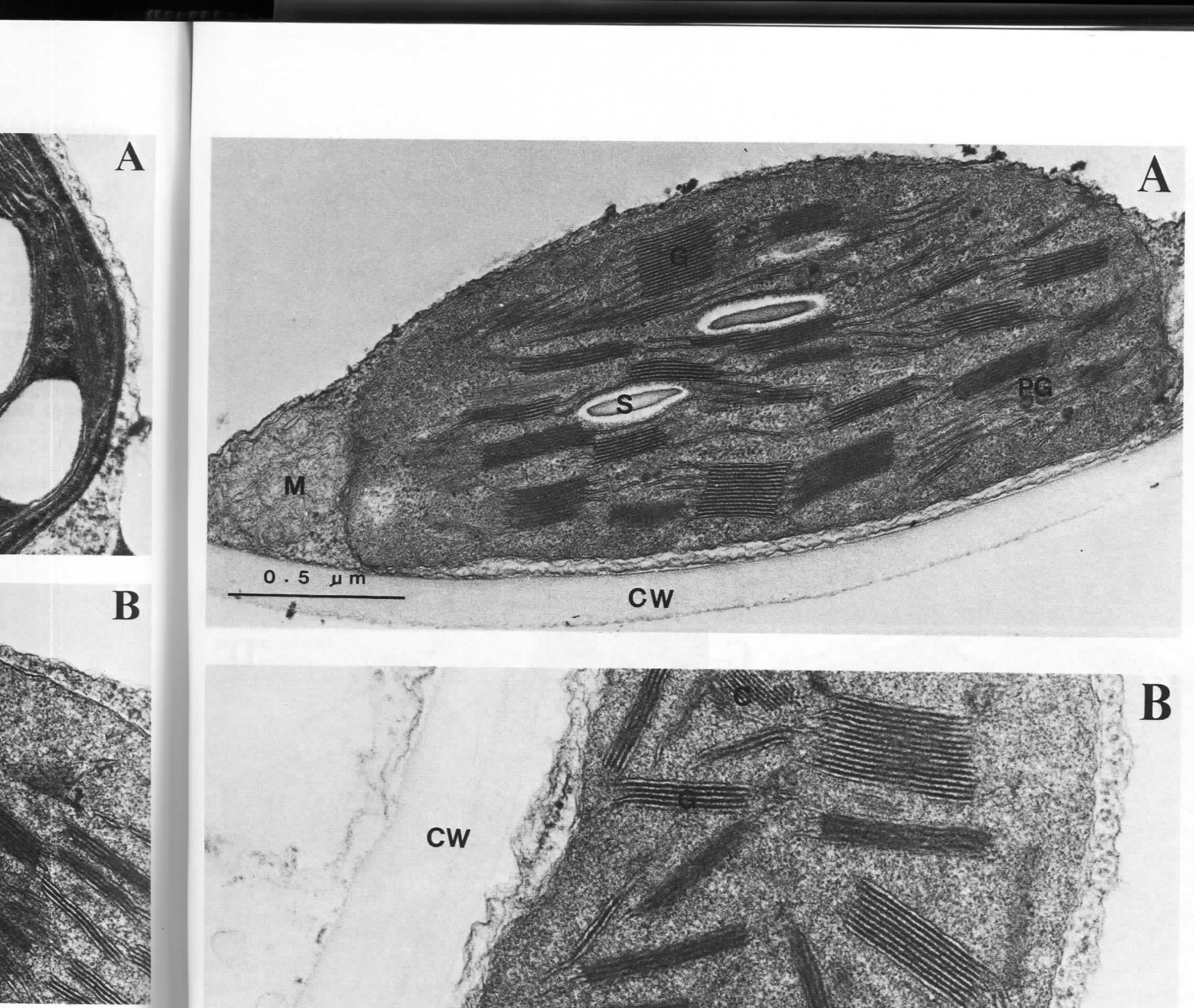

from 5-day-old , control plant; ystalline inclus

ried out for 3 ter bath therwas $140 \mu \mathrm{mol}$ he addition of of the reaction ermined spec$420 \mathrm{~nm}$.

y affected gerd, but signifie plants used, ab. 1).

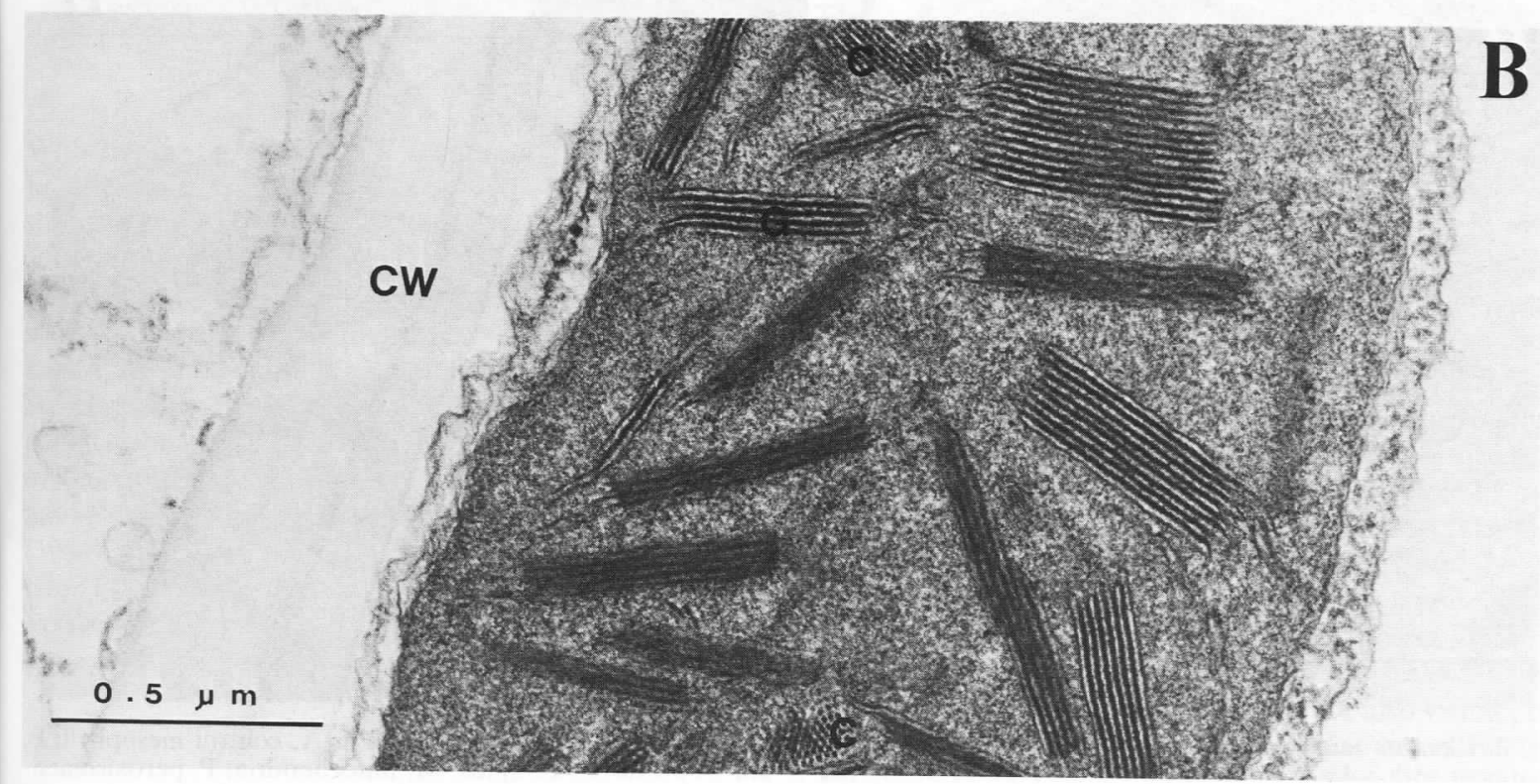

Fig. 2. Electron micrographs showing chloroplasts from 5-day-old wheat cotyledon cv. Esquilache greened for $48 \mathrm{~h}$. A, control mesophyll; B, treatment with $340 \mu M$ isoproturon; C, crystalline inclusions; CW, cell wall; M, mitochondria; PG, plastoglobuli.

\section{Ultrastructure}

Cells examined were always taken from the tissue of the central part of the mesophyll, thus avoiding variations in results with regard to different parts of the cotyledon. No differences in the shapes of the plastids could be detected for the various plants and treatments. Changes in the chloroplast ultrastructure caused by the herbicide in the cotyledon mesophyll cells were observed in all three plants studied (Tab. 2). With isoproturon in the range
34-340 $\mu M$ the chloroplasts of the two wheat cultivars contained a higher number of grana with fewer thylakoids per granum, but the granum stacks were broader than in the control (Figs 1 and 2). Hardly any starch was present in the isoproturon-treated wheat plants. Crystalline inclusions like those reported by Golvano et al. (1982) appeared in the stroma near the thylakoids in the two wheat cultivars. The changes in the chloroplast ultrastructure were visible in both cultivars as early as $48 \mathrm{~h}$ after the simultaneous application 


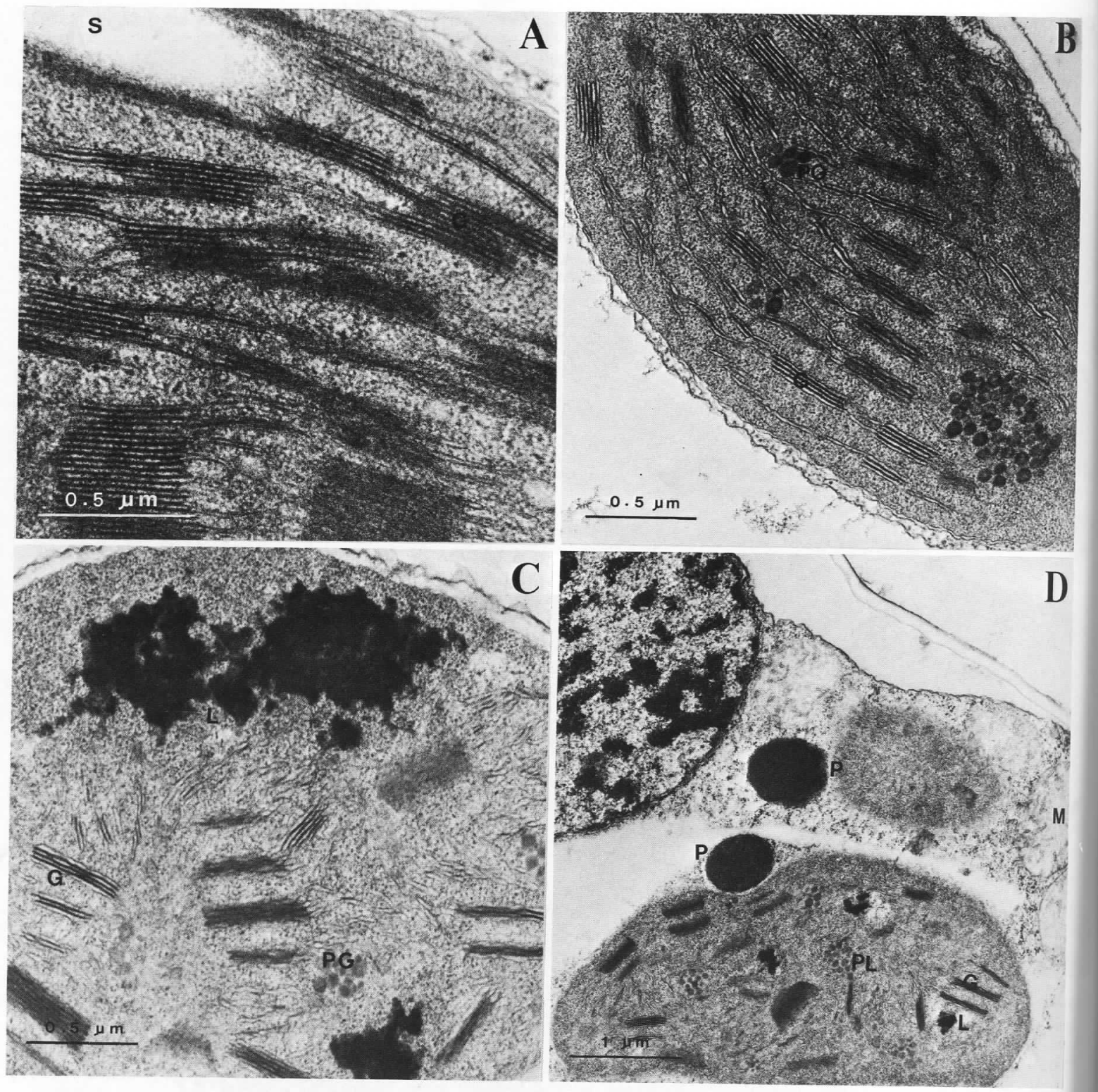

Fig. 3. Electron micrographs of chloroplasts from 5-day-old L. rigidum cotyledon greened for $48 \mathrm{~h}$. A control mesophyll; treatment with $3.4 \mu M$ isoproturon; $\mathrm{C}$ and $\mathrm{D}$, treatment with $17 \mu M$ isoproturon; $\mathrm{L}$, lipids; $\mathrm{M}$, mitochondria; $\mathrm{P}$, peroxisomes

of herbicide and exposure to light, but no further modifications of the ultrastructure were observed during the rest of the experiments in cv. Castan. However, further changes were observed in cv. Esquilache after $60 \mathrm{~h}$. These ultrastructural changes (such as swelling of thylakoids) observed at later periods in this cultivar became gradually more pronounced, although no disintegration in the internal membrane system was observed, nor rupture of the chloroplast envelope. At 3.4 $\mu M$ no effect on the cellular ultrastructure of either wheat $\mathrm{cv}$. was found.

With regard to growth and mesophyll ultrastructure, cv. Castan was found to be less affected by the herbicide. The main changes observed in the ultrastructure were alterations in the development of the internal chloroplast membranes: an increase in the number of grana, a decrease in number of thylakoids per granum and a reduction in the number of stroma lamellae. When applying other herbicides, certain authors have obtained similar results with regard to the internal structure of chloroplasts. Wergin and Potter (1975) found more elongated grana, with fewer compartments unconnected to stroma lamellae on application of fluometuron in velvetleaf (Abutilum theophrasti L.) seedlings. 
Tab. 2. Effect of isoproturon concentrations $(\mu M)$ on the plastid structure of young leaves of $T$. sativum cvs Esquilache and Castan and $L$. rigidum Gaud. after $40 \mathrm{~h}$ of continuous illumination. Each value is the mean \pm SD of 30 plastids of at least five different block samples.

${ }^{*}, * * * * *$, Differ from the control at 5,1 and $0.1 \%$ level according to Student's $t$-test.

\begin{tabular}{|c|c|c|c|c|c|c|c|c|}
\hline \multirow[t]{2}{*}{ Parameters } & \multicolumn{3}{|c|}{$T$. sativum $\mathrm{cv}$. Esquilache } & \multicolumn{3}{|c|}{ T. sativum cv. Castan } & \multicolumn{2}{|c|}{ L. rigidum } \\
\hline & $0 \mu M$ & $34 \mu M$ & $340 \mu M$ & $0 \mu M$ & $34 \mu M$ & $340 \mu M$ & $0 \mu M$ & $3.4 \mu M$ \\
\hline $\begin{array}{l}\text { Chloroplast area } \\
\left(\mu \mathrm{m}^{2}\right)\end{array}$ & $4.2 \pm 2.2$ & $4.2 \pm 1.3$ & $6.3 \pm 1.3^{*}$ & $6.0 \pm 0.5$ & $5.0 \pm 0.9$ & $8.0 \pm 1.3^{* *}$ & $6.0 \pm 1.6$ & $7.0 \pm 4.1$ \\
\hline $\begin{array}{l}\text { Chloroplast } \\
\text { perimeter }(\mu \mathrm{m})\end{array}$ & $8.2 \pm 1.2$ & $8.7 \pm 1.2$ & $10.7 \pm 1.7^{*}$ & $10.2 \pm 0.2$ & $10.2 \pm 1.1$ & $12.0 \pm 1.2$ & $10.4 \pm 1.8$ & $10.4 \pm 1.6$ \\
\hline $\begin{array}{l}\text { Maximum } \\
\text { diameter }(\mu \mathrm{m})\end{array}$ & $3.0 \pm 0.4$ & $3.3 \pm 0.5$ & $4.0 \pm 0.9$ & $3.6 \pm 0.4$ & $4.1 \pm 0.4$ & $4.4 \pm 1.3^{*}$ & $3.9 \pm 0.9$ & $3.7 \pm 0.8$ \\
\hline $\begin{array}{l}\text { Grana per } \\
\text { plastid }\end{array}$ & $14.0 \pm 5.3$ & $24.0 \pm 4.9^{* * *}$ & $24.0 \pm 6.9^{* * *}$ & $18.0 \pm 4.0$ & $29.0 \pm 5.0^{* *}$ & $34.0 \pm 4.0^{* * *}$ & $43.2 \pm 7.9$ & $16.1 \pm 3.6^{* * *}$ \\
\hline $\begin{array}{l}\text { Granum, area } \\
\left(\mu \mathrm{m}^{2}\right)\end{array}$ & $0.04 \pm 0.01$ & $0.03 \pm 0.01$ & $0.04 \pm 0.01$ & $0.05 \pm 0.01$ & $0.05 \pm 0.01$ & $0.04 \pm 0.01$ & $0.03 \pm 0.03$ & $0.02 \pm 0.01$ \\
\hline $\begin{array}{l}\text { Granum width } \\
(\mu \mathrm{m})\end{array}$ & $0.3 \pm 0.1$ & $0.3 \pm 0.1$ & $0.4 \pm 0.1^{* *}$ & $0.3 \pm 0.1$ & $0.4 \pm 0.1^{*}$ & $0.4 \pm 0.1^{*}$ & $0.2 \pm 0.1$ & $0.3 \pm 0.1$ \\
\hline $\begin{array}{l}\text { Thylakoids per } \\
\text { granum }\end{array}$ & $7.5 \pm 3.1$ & $6.8 \pm 3.1^{*}$ & $4.7 \pm 2.0^{* *}$ & $8.0 \pm 4.0$ & $6.9 \pm 3.0^{*}$ & $4.9 \pm 2.0^{* *}$ & $4.5 \pm 1.9$ & $4.1 \pm 1.0^{* *}$ \\
\hline $\begin{array}{l}\text { Stacking } \\
\text { degree }(\%)\end{array}$ & $32 \pm 9$ & $42 \pm 7^{*}$ & $41 \pm 6^{*}$ & $46 \pm 2$ & $51 \pm 6$ & 44 & 35 & $\pm 5^{* * *}$ \\
\hline $\begin{array}{l}\text { Starch grains } \\
\text { per } \mu \mathrm{m}^{2} \text { plastid } \\
\text { cross section }\end{array}$ & $0.5 \pm 0.6$ & $0.0 \pm 0.0$ & $0.0 \pm 0.0$ & $2.1 \pm 1.2$ & $0.0 \pm 0.0$ & $0.0 \pm 0.0$ & $0.7 \pm 0.4$ & $0.0 \pm 0.0$ \\
\hline
\end{tabular}

With bentazon, Meier and Lichtenthaler (1981) found broader and higher grana stacks, a higher degree of stacking and a reduction of starch. With regard to shade adaptation, our results were similar in part to those of Meier and Lichtenthaler with bentazon. In our experiments, the grana in the mesophyll of both cultivars contained fewer thylakoids as is the case with fluometuron. Starch was not found in the chloroplasts of any of the plants, which indicated either an altered photosynthesis or the utilization of carbohydrates. Absence of starch has been reported by Ashton et al. (1963) and Hill et al. (1968) in plants treated with atrazine. Geronimo and Herr (1970) reported the disappearance of starch from tobacco chloroplasts after pyroclor treatment, Anderson and Schaelling (1970) after treatment of bean plants

Tab. 3. Effect of isoproturon on ferricyanide photoreduction by different preparations of subchloroplast particles. The reaction mixture contained $33 \mathrm{mM}$ Tricine- $\mathrm{KOH} \mathrm{pH} \mathrm{8.5,1.7} \mathrm{mM}$ potassium ferricyanide, 180 (wheat) or 160 (weed) $\mu$ g chlorophyll as chloroplast suspensions, and isoproturon at the concentrations indicated, in a final volume of $3 \mathrm{ml}$. Numbers in parentheses are ferricyanide inhibition percentages.

\begin{tabular}{cccc}
\hline \multirow{2}{*}{$\begin{array}{c}\text { Isoproturon } \\
\text { concentration } \\
\mu M\end{array}$} & \multicolumn{3}{c}{$\begin{array}{c}\text { Ferricyanide photoreduced }\left[\mu \mathrm{mol} \mathrm{O}_{2}\right. \\
\left.(\mathrm{mg} \text { chlorophyll })^{-1} \mathrm{~h}^{-1}\right]\end{array}$} \\
\cline { 2 - 4 } & Castan & Esquilache & L. rigidum \\
\hline 0 & 77 & 81 & 225 \\
1.2 & $38(51)$ & $41(49)$ & $105(54)$ \\
4.8 & $41(46)$ & $36(56)$ & $95(58)$ \\
\hline
\end{tabular}

with pyrazon, and Meier and Lichtenthaler (1981) with bentazon.

In Lolium rigidum, isoproturon at $3.4 \mu M$ affects the ultrastructure of mesophyll cells after $48 \mathrm{~h}$ treatment. The internal lamellar sytem formed was reduced and no starch was present (Tab. 2, Fig. 3A,B). With $17 \mu M$ a certain number of plastoglobuli, and a substance fully stained by $\mathrm{OsO}_{4}$ was noted in several areas of chloroplast stroma. As can be seen in Fig. 3C, this substance has a lipid appearance and may be caused by a destruction of the lamellar system of the chloroplasts. The lipid increase resembled that found by Harris and Dodge (1972) in the flax cotyledon leaf chloroplast upon simultaneous application of paraquat and exposure to light.

Extremely electron dense microbodies close to the chloroplasts and the mitochondria were also visible, but the mitochondria and nuclei appeared to be unaffected. Preliminary data indicate that such microbodies are peroxisomes (Fig. 3D), since they exhibit a positive peroxidase and catalase reaction when assayed with diaminebenzidine (M. R. de Felipe, J. M. Pozuelo and M. M. Lucas, unpublished results). An increase in peroxidase and catalase activities in tissues affected by herbicides has been reported by other authors (Tolbert et al. 1968, Gregory 1968, Yamazaki and Tolbert 1970).

Following the severe herbicide-induced alterations, the tonoplast was broken and, as a consequence, the loss of cellular compartments and integrity took place. The rupture of cellular organelles could be partly due to the effect of the vacuolar components, such as hydrolytic enzymes (Matile 1966, Villiers 1971). In many respects the herbicide-induced changes in some rye grass 
chloroplasts were similar to those which occur during natural senescence (Butler and Simon 1971).

\section{Photosynthetic activity}

As mentioned above, isoproturon prevented the accumulation of starch in cotyledons (Figs 1 and 2), which indicated that this herbicide strongly inhibits the photosynthetic activity of the plant. However, such inhibition might be only a secondary effect - the result of a profound ultrastructural alteration. In order to see whether isoproturon could directly influence photosynthetic ability, its effect on the Hill reaction was assayed in subchloroplast particles of the wheat and weed plants (Tab. 3). Using potassium ferricyanide as Hill oxidant, the results obtained suggested that isoproturon can diminish this photosynthetic activity in the three plants, and that all three exhibit a similar sensitivity to the herbicide.

If the partial photosynthetic reaction studied here is representative of the whole photosynthetic activity, one might think that isoproturon exerts a differential effect when supplied to the entire plant (in vivo) or to chloroplasts (in vitro). The different effect could be due to a diverse destination of the herbicide in vivo depending on the plant type. In fact, the plant type might condition several physiological processes, such as the absorption, translocation and/or the chemical modification of the herbicide.

Finally, our results point once more to the danger of the indiscriminate use of herbicides in the field. Their effects on any particular crop, therefore, should first be taken into account.

Acknowledgements - The authors wish to acknowledge the technical help received from Ms María del Carmen de Mesa and Ms María Luisa Melendo and are grateful to Mr Fernando Pinto for his assistance in the use of the electron microscope. The isoproturon was kindly supplied by the Condor representative in Spain of Rhone Poulec (France).

\section{References}

Arnon, D. I. 1949. Copper enzymes in isolated chloroplasts. Polyphenoloxidase in Beta vulgaris. - Plant Physiol. 24: $1-15$.

Anderson, J. L. \& Schaelling, J. P. 1970. Effects of pyrazon on bean chloroplast ultrastructure. - Weed Sci. 18: 455-458.

Ashton, F. M., Gifford, E. M. \& Bisalputra, T. 1963. Structural changes in Phaseolus vulgaris induced by atrazine. II. Effects on the fine structure of chloroplasts. - Bot. Gaz. 124: $336-343$
Butler, R. D. \& Simon, E. W. 1971. Ultrastructural aspects of senescence in plants. - Adv. Gerontol. Res. 3: 73-129.

Fedtke, C., Deichgräber, G. \& Schnepf, E. 1977. Herbicide induced changes in wheat chloroplast ultrastructure and chlorophyll $a / b$ ratio. - Biochem. Physiol. Pflanz. 171: 307312 .

Geronimo, J. \& Herr, J. W. 1970. Ultrastructural changes tobacco chloroplasts induced by pyriclor. - Weed. Sci. 18 $48-53$

Golvano, M. P., de Felipe, M. R. \& Cintas, A. M. 1982. Inft ence of nitrogen sources on chloroplast development in wheat seedlings. - Physiol. Plant. 56: 353-360.

González Ponce, R. \& Rodríguez Señas, J. 1983. Experiment with isoproturon for the control of weeds in winter cereal crops. - Weed Res. 23: 39-43.

Gregory, R. P. F. 1968. An improved preparative method for spinach catalase and evaluation of some of its properties. Biochim. Biophys. Acta 159: 429-439.

Harris, N. \& Dodge, A. D. 1972. The effect of paraquat 0 flax cotyledon leaves. Changes in fine structure. - Plant 104: 201-209.

Hill, E. R., Putala, E. C. \& Vengris, J. 1968. Atrazine induce ultrastructural changes of barnyard grass chloroplasts. Weed Sci. 16: 377-382

Klein, S. \& Neuman, J. 1966. The greening of etiolated bea leaves and development of chloroplast fine structure in absence of photosynthesis. - Plant Cell Physiol. 7: 115-118

Matile, Ph. 1966. Enzyme der Vakuolen aus Wurzelzellen vo Maiskeimlingen. Ein Beitrag zur funktionellen Bedeutun der Vakuole bei der intrazellularen Verdauung. - Z. Naturforsch. 216: 871-878.

Meier, D. \& Lichtenthaler, H. K. 1981. Ultrastructural devel opment of chloroplast in radish seedling grown at high and low-light conditions and in presence of the herbicide bentazon. - Protoplasma 107: 195-207.

Moreland, D. E. 1980. Mechanisms of action of herbicides. Annu. Rev. Plant Physiol. 31: 597-638.

Pozuelo, J. M. \& Ulrich, A. 1967. El fósforo en la remolach azucarera (Beta vulgaris) I. Efectos del fósforo en el desar rollo de la planta. - An. Edaf. Agr. 26, núms. 7-8: 1161 1182.

Reynolds, E. S. 1963. The use of lead citrate at high $\mathrm{pH}$ as an electron opaque stain in electron microscopy. - J. Cell Biol 17: $208-213$

Tolbert, N. E., Oeser, A., Kisaki, T., Hageman, R. H. \& Yamazaki, R. K. 1968. Peroxisomes from spinach leaves containing enzymes related to glycolate metabolism. - J. Biol. Chem. 243: 5179-5184

van Rensen, J. J. S. 1982. Molecular mechanism of herbicide action near photosystem II. - Physiol. Plant. 54: 515-521.

Villiers, T. A. 1971. Lysosomal activities of the vacuole in damaged and recovering plant cells. - Nature 233: 57-58.

Wergin, W. P. \& Potter, J. R. 1975. The effects of fluometuron on the ultrastructural development, chlorophyll accumulation and photosynthetic competence in developing velvet leaf seedlings. - Pestic. Biochem. Physiol. 5: 265-279.

Whatley, F. R. \& Arnon, D. I. 1963. Photosynthetic phospho rylation in plant. - In Methods in Enzymology (S. P. Colowick and N. O. Kaplan, eds), Vol. VI, pp. 308-313. Aca demic Press.

Yamazaki, R. K. \& Tolbert, N. E. 1970. Enzymic characteization of leaf peroxisomes. - J. Biol. Chem. 245: 51375144 . 